Full length article

\title{
Multi-criteria decision analysis to assess the environmental and economic performance of using recycled gypsum cement and recycled aggregate to produce concrete: The case of Catalonia (Spain)
}

\author{
Sindy Suárez Silgado ${ }^{\mathrm{a}}$, Lucrecia Calderón ${ }^{\mathrm{b}}$, Santiago Gasso $^{\mathrm{c}}$, Xavier Roca ${ }^{\mathrm{d}}$ \\ ${ }^{a}$ Universidad Antonio Nariño, Faculty of Arts, Architecture Program, Group of City, Environment and Popular Habitat, Cra. 10 \# 17-35 Barrio Ancón, Ibagué, Colombia \\ ${ }^{\mathrm{b}}$ Universitat Politècnica de Catalunya, Technology Department of Architecture, Av. Diagonal 649, 08028, Barcelona, Spain \\ ${ }^{\mathrm{c}}$ Universitat Politècnica de Catalunya, Departament of Project and Construction Engineering, Group of Earth Science (GES), C/Colom, 11, Ed. TR5, 08222, Terrassa, Barcelona, Spain \\ d Universitat Politècnica de Catalunya, Departament of Project and Construction Engineering, Group of Construction Research and Innovation (GRIC), C/Colom, 11, Ed, TR5, 08222 Terrassa, \\ Barcelona, Spain
}

\section{A R T I C L E IN F O}

\section{Keywords:}

Recycled aggregate

Concrete

Impact

Construction

Recycled gypsum cement

Multi-criteria optimization

\begin{abstract}
A B S T R A C T
The production of virgin raw materials used in construction and the generation of construction and demolition waste (CDW) are key environmental issues in the construction industry. Portland cement and concrete are used extensively in the construction sector. Processing of CDW to produce recycled gypsum cement and recycled aggregates (RA) and their use in the production of structural and non-structural concrete are one way of slowing natural resource depletion and reducing the amount of CDW landfilled. This study proposes the application of multi-criteria decision analysis (MCDA) to compare the production of "green" concretes made from recycled gypsum cement (RGC) and RA with the production of conventional concrete made from natural aggregate and ordinary Portland cement. The VIKOR MCDA method was employed to determine the best or a set of good alternative(s) for concrete production, considering environmental and economic criteria. The life cycle assessment method was used to select the environmental evaluation criteria, and the reference cost of producing concrete alternatives in Spain was used to determine economic criteria. The results of this study, in which environmental and economic criteria were considered of equal weight, or one of the two criteria was given greater weight, showed that the best option for structural and non-structural concrete was the use of RGC and RA. In both cases, the worst alternative was conventional concrete. In conclusion, we found that the use of RGC and RA in concrete production is positive because it replaces the original raw material, reduces the environmental impact, and lowers the economic costs.
\end{abstract}

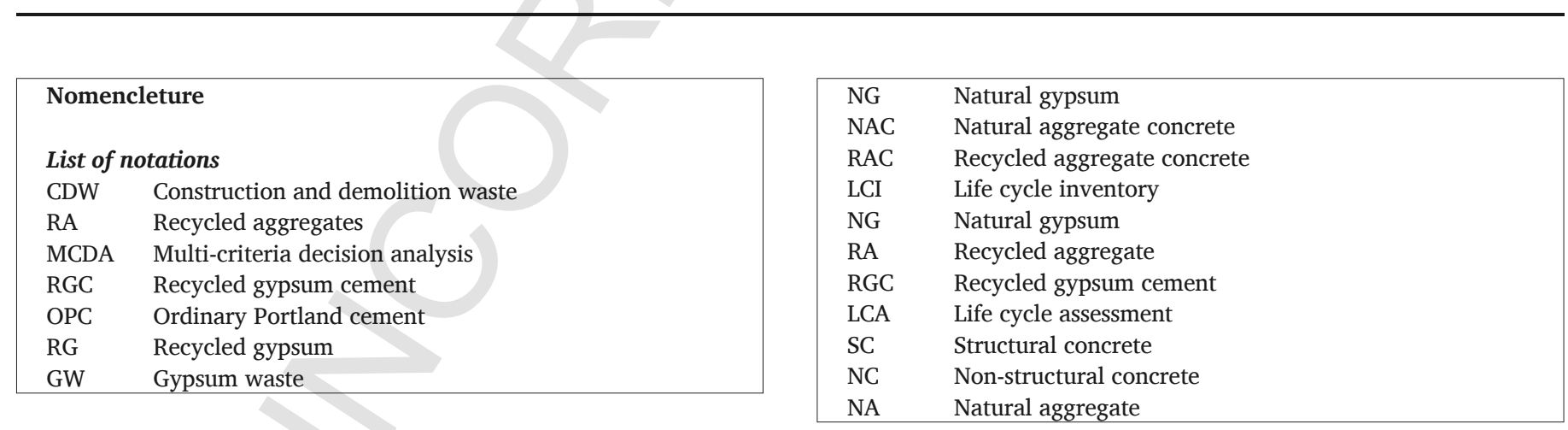

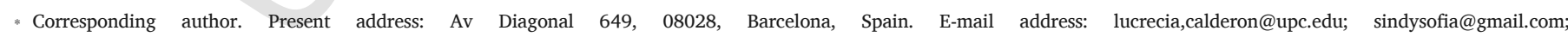
santiago.gasso@upc.edu; director.eseiaat@upc.edu

Email address: lucrecia.calderon@upc.edu (L. Calderón)
} 


\begin{tabular}{|ll|}
\hline RMA & Recycled mixed aggregate \\
NGC & Natural gypsum cement \\
NCA & Natural coarse aggregate \\
NFA & Natural fine aggregate \\
RCCA & Recycled concrete coarse aggregate \\
RMCA & Recycled mixed coarse aggregate \\
GWg & Global warming \\
OD & Ozone depletion \\
A & Acidification \\
E & Eutrophication \\
RO & Respiratory organics \\
ME & Mineral extraction \\
C & Carcinogens \\
NC & Non- carcinogens \\
NRE & Non-renewable energy \\
RI & Respiratory inorganics \\
LO & Land occupation \\
\hline
\end{tabular}

\section{Introduction}

As civilization has developed and the world population has grown, one of the biggest environmental concerns has become the high consumption of natural resources and energy. One of the main consumers is the construction industry, since it requires large quantities of natural resources. According to USGS (2017), in 2015, the world production of ordinary Portland cement (OPC) was 4.1 billion metric tonnes. Although data differ from country to country, around half of the world's OPC is used to make concrete; the rest is used in mortars, screeds, stucco, coatings, soil stabilization and other applications (Smith et al., 2002). The cement industry, like any other construction industry, is tackling major challenges relating to energy resources, $\mathrm{CO}_{2}$ emissions and the use of recycled materials instead of raw materials (Imbabi et al., 2012).

Considerable quantities of construction and demolition waste (CDW) are produced during the construction and demolition of buildings and civil infrastructure (Chen and Weisheng, 2017). CDW is one of the main waste streams in the EU, accounting for around 900 million tonnes per year (Eurostat, 2010; Ossa et al., 2016). Accordingly, special attention is devoted to CDW management at global and European level. In European legislation, this issue is addressed in Directive 2008/98/EC, which set the target for the recovery and recycling of non-hazardous CDW at a minimum of $70 \%$ of its weight by 2020 .

CDW consists of numerous materials, including concrete, brick, gypsum, wood, glass, metal, plastic, solvents, asbestos and excavated soil, much of which can be recycled. However, most of this waste ends up in landfill, even though the space available for landfill is increasingly scarce (Hiete et al., 2011).

Due to the considerable environmental and economic impact of the construction industry on resource depletion and waste generation, new strategies must be found for producing construction materials that are not based on original raw material, and for managing CDW in such a way that dependency on landfill is reduced. The use of recycled material from CDW is becoming a crucial strategic step for managing CDW, to improve the sustainability of the construction industry (Lu and Yuan, 2011; Ghanimeh et al., 2016).

Within this framework, it should be noted that after clay materials, gypsum waste (GW) is the second largest contributor to the CDW stream (Godinho-Castro et al., 2012). Over 15 million tonnes of gypsum waste is sent to landfill annually in Europe, the USA and Asia (GRI, 2014). In 2002, EU Council Decision 33/2002 strengthened criteria for deciding which waste could be landfilled and in which type of landfills. It was decided that non-hazardous gypsum-based materials should be disposed of only in landfills for non-hazardous waste in cells (due to the risk of hydrogen sulphide gas generation). Full implementation of the Council Decision on Waste Acceptance Criteria in all EU countries will significantly increase the cost of landfilling and will lead to an increase in the availability of recycled gypsum (RG). Therefore, it is important to recycle or reuse GW to fulfil current legislation and protect the health and welfare of human beings against environmental pollution.

The use of RG instead of natural gypsum (NG) in ordinary Portland cement (OPC) manufacture, together with its use in plasterboard plants, are feasible alternatives to meet the environmental challenges of managing RG from CDW. In the case of OPC manufacture, NG is added to OPC in the grinding process to control the rate of hardening or the setting time: generally around $2-10 \%$ of ground-up Portland cement is comprised of gypsum (Imbabi et al., 2012).

Previous studies have examined the technical feasibility of using RG instead of NG in the production of OPC, by evaluating the mechanical and chemical properties of the resulting product. The results demonstrated that the properties were similar for both types of cements, and confirmed that RG can be used as an alternative to NG in the production of OPC (Chandara et al., 2009; Morales Martinez, 2010; Ahmed et al., 2011).

Notably, concrete is the most heavily consumed material in the construction industry, and the second most consumed material on earth after water. It is also the largest fraction of CDW. Thus, recycling of concrete is considered an important option to avoid landfill and reduce consumption of the virgin resources used in construction industry (Srubar, 2015).

The recycled concrete aggregates (RCA) derived from CDW that can be used in both structural and non-structural concrete could help reduce depletion of natural mineral resources and the amount of CDW being put in landfill (Behera et al., 2014; Tošić et al., 2015).

Several researchers have studied the durability of recycled aggregate concrete (Medina et al., 2012; Anastasiou et al., 2014; de Bravo et al., 2015; Faella et al., 2016), as well as its water absorption by immersion and capillarity (de Bravo et al., 2015), resistance to penetration of chloride ions in the concrete (Corinaldesi and Moriconi, 2009; Evangelista and De Brito, 2010; de Bravo et al., 2015) and compressive strength (Sánchez de Juan, 2004; Alaejos, 2008; Lima et al., 2013; González-Corominas et al., 2014; Pepe et al., 2014).

Marinković et al. (2010) and Tošić et al. (2015) in Serbia performed a comparative LCA for different types of used aggregate and transport scenarios in concrete production. In addition, they used a multi-criteria optimization method for natural aggregate concrete (NAC) and recycled concrete aggregate (RCA), based on their local life cycle inventory (LCI), and taking into account technical, economic and environmental criteria. The results showed that concrete with a 50\% replacement ratio of coarse aggregate with RCA could be an optimal solution. The analysis identified taxes on river aggregate, taxes on landfill, and subsidies for using RCA as feasible measures to establish similar costs in natural aggregate and recycled aggregate. In addition, they found that energy savings in recycling projects are only possible if recycling plants are located close to building sites. Others author such us Dong et al. (2015) and Hossain et al. (2016) in Hong Kong or Turk et al. (2015) in Slovenia conducted LCA studies to evaluate the environmental consequences of NAC and RCA application. They also found that closeness of recycling plants to building sites is a key factor to ensure environmental benefits.

Moreover, the economic viability of recycling plants for CDW has been shown. Coelho and De Brito (2013a) and Coelho and De Brito (2013b) found that, even in the absence of government intervention, there was a clear alignment between economic viability and environmental benefits of the operation of a CDW recycling plant.

In addition, Tam (2008) compared the costs and benefits of the current practice of obtaining aggregates and concrete recycling methods. 
The results of this study showed negative net profit for the current practice of obtaining aggregates, but positive net profit for the concrete recycling method.

Various studies have evaluated the production of concrete made with RA. However, they generally examined the physical, chemical and mechanical properties of the material; the environmental and economic performance of using CDW in the production of concrete was not evaluated in depth. Suárez et al. (2016) found that the environmental impact on the evaluated categories was slightly lower when RG (recycled gypsum) was used instead of NG (natural gypsum) in the production of cement. The use of recycled aggregate (RA) and recycled gypsum cement (RGC) in structural and non-structural concrete has not been evaluated environmentally or economically.

The life cycle assessment (LCA) method is one of the most valuable approaches for implementing a comprehensive environmental impact analysis of any product or system (Kylili and Fokaides, 2016). LCA has been used successfully to assess the environmental impacts of construction products and services (Ortiz et al., 2010; Zabalza Bribián et al., 2011; Tošić et al., 2015). However, it is only suitable for assessing environmental criteria. To include economic criteria in the study of different concrete alternatives, a multi-criteria method should be considered. This will ensure that the best option can be selected according to both environmental and economic criteria.

The feasibility of using recycled gypsum cement and recycled aggregate to produce structural and non-structural concrete must be analysed in terms of environmental quality and economic benefit, in order to increase the recycling rates of these materials and improve the overall sustainability of CDW management. This is essentially a multifaceted problem (environmental and economic in nature) involving a range of considerations, often with complex trade-offs among them. Consequently, a suitable way to address this issue could be multi-criteria decision analysis (MCDA) (Quijano, 2012; Vahabzadeh et al., 2015). MCDA is a group of methods and procedures that can be used specifically for multiple conflicting criteria to help decision-makers, individuals or groups to rank, select and/or compare alternatives (Belton and Stewart, 2002; Hermann et al., 2007).

A wide range of MCDA methods have been developed, e.g. Jato-Espino et al. (2014) reported 25 different MCDA methods after reviewing 88 research papers related to the application of MCDA in the construction industry. Several studies combining LCA and MCDA have been reported in previous works including, among others, analytic hierarchy process (Reza et al., 2011; Kim et al., 2013), data envelopment analysis (Tatari and Kucukvar, 2011), the integrated value model for sustainable assessment (Pons and Aguado, 2012), fuzzy extended analytical hierarchy process (Akadiri et al., 2013), and VIKOR (Tošić et al., 2015; Vučijak et al., 2016).

This paper proposes an MCDA using the VIKOR approach to evaluate the environmental and economic impact of the production of concrete using RGC and RA, particularly in Catalonia (Spain). We used the VIKOR method because, as shown in the work of Vahabzadeh et al. (2015), it is an extended method proposed to solve MCDA problems with conflicting and incommensurable criteria, which has been applied successfully in the field of environment and materials engineering. VIKOR is a helpful tool, particularly when the decision-maker is not able, or does not know how to express his/her preference at the beginning of the system comparison (Mir et al., 2016).

The current study aims to give a contribution to the building industry and sustainability research in at least two aspects. First, it widens knowledge about environmental and economic performance of recycled material to produce "green" concretes. It also develops an appropriate methodology for future decision-making that combines environmental and economic aspects, and provides building stakeholders with a new way of prioritizing materials selection, thereby facilitating the sustainability of CDW recycling. Additionally, no relevant studies in the literature were found that focused specifically on the application of MCDA using the VIKOR method to determine the environmental and economic implications of using RGC and RA to produce structural and non-structural concrete.

\section{Multi-criteria decision analysis method}

The MCDA was selected in this paper as a suitable approach for the sustainable evaluation of complex problems with a high degree of uncertainty, conflicting goals, and multiple interests and perspectives (Quijano, 2012; Cinelli et al., 2014; Vahabzadeh et al., 2015).

The aim of MCDA is to provide solutions and propose the best or a set of good alternative(s) for solving problems with multiple criteria. The results will be affected by decision-makers' priorities when they rank the criteria and sub-criteria. MCDA methods can be applied to both quantitative and qualitative criteria, to establish common characteristics, in opposition to other criteria such as the incommensurable units, and the difficulty in the design/selection of alternatives (Pohekar and Ramachandran, 2004).

The VIKOR MCDA method was applied here. This method was developed for the multi-criteria optimisation of complex systems (Bahraminasab and Jahan, 2011) and is widely used nowadays. It focuses on ranking and selecting a set of alternatives with conflicting and incommensurable (different units) criteria, and provides a solution according to the measure of closeness to the ideal solution (Cinelli et al., 2014; Mir et al., 2016).

According to several researchers (García and Luís, 2004; Opricovic and Tzeng, 2007; García and $\mathrm{M}^{\circ}$ Del Socorro, 2009), the main steps in the process of multi-criteria decision-making are as follows: a) identification of alternatives; b) determination of criteria; c) evaluation of alternatives; d) application of a multi-criteria analysis method; e) selection of optimal alternatives.

Fig. 1 shows the flow chart of the steps followed in the current study.

\subsection{Identification of alternatives}

In this stage, concrete alternatives were defined. We took into account studies in this field in which only the technical performance of the material was evaluated (physical, chemical or mechanical properties) (Table 1). These studies demonstrated the technical feasibility of different types of concrete. The alternatives and a summary of different proportions and characteristics of the materials used in the manufacture of the concrete are shown in Table 1. The alternatives are based on obtaining concrete of similar strength and mechanical behaviour, whilst maintaining the same functionality.

For the structural concrete, the dosage used by López (2008) was followed, which guarantees a resistance of $35 \mathrm{~N} / \mathrm{mm}^{2}$ (C35/45). This resistance covers most of the concrete that is manufactured in Spain for civil works. This first group of concrete was made with $375 \mathrm{~kg} / \mathrm{m}^{3}$ of cement and $187.5 \mathrm{~kg}$ of water; therefore, the $\mathrm{w} / \mathrm{c}$ ratio was 0.50 .

For the manufacture of non-structural concrete, the dosage recommended by Sánchez de Juan (2011) was followed, in which $250 \mathrm{~kg}$ of cement (CEM I $42.5 \mathrm{R}$ ) and $187.5 \mathrm{~kg}$ of water, that is, a water/cement ratio of 0.75 was used to obtain concrete of a strength of $15-16 \mathrm{~N} / \mathrm{mm}^{2}$ (C16/20) for non-structural use.

The percentage of replacement of recycled aggregate by natural arid is based on the results of previous studies (Alaejos, 2008; Sánchez de Juan et al., 2011), which guarantee that with this percentage there is no decrease in the resistance or in other properties of the concrete such as durability. This enables us to undertake an environmental evaluation of concrete that complies with the technical requirements.

Alaejos (2008) and Sánchez de Juan et al. (2011) concluded that, in the case of concrete with structural characteristics, $20 \%$ is the limit of 


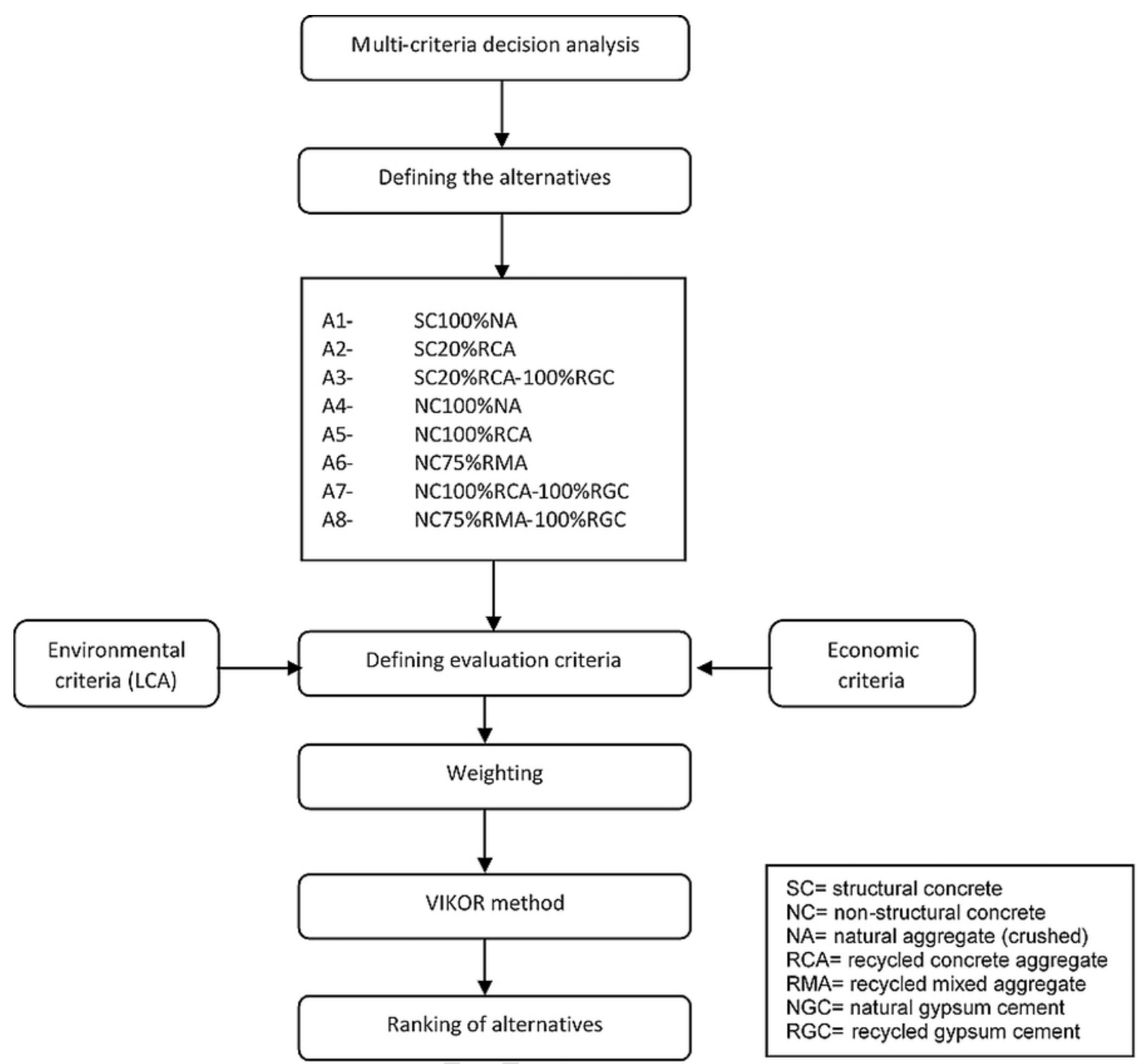

Fig. 1. Summary of multi criteria decision analysis steps.

Table 1

Structural and non-structural concrete alternatives (main characteristics per $\mathrm{m}^{3}$ ).

\begin{tabular}{|c|c|c|c|c|c|c|c|c|}
\hline Alternatives & Strength classe & $\mathrm{w} / \mathrm{c}$ (effective) & Water (kg) & NGC (kg) & RGC (kg) & NCA (kg) & NFA (Kg) & RCCA (kg) \\
\hline SC100\%NA & \multirow[t]{3}{*}{ Class C 35/45 } & 0.50 a; b; c; e & $187.5^{b ; c}$ & $375^{b ; c}$ & & $1125^{d}$ & $750^{d}$ & \\
\hline SC20\%RCA & & 0.50 a; b; c; e & $187.5^{b ; c}$ & $375^{b ; c}$ & & $900^{d}$ & $750^{d}$ & $225^{d}$ \\
\hline SC $20 \%$ RCA-100\%RGC & & 0.50 a; b; c; e & $187.5^{b ; c}$ & & $375^{\mathrm{b} ; \mathrm{c}}$ & $900^{d}$ & $750^{d}$ & $225^{d}$ \\
\hline NC100\%NA & \multirow[t]{5}{*}{ Class C16/20 } & $0.75^{d}$ & $187.5 \mathrm{~b} ; \mathrm{c} ; \mathrm{d}$ & $250^{d}$ & & $1107^{\mathrm{d}}$ & $886^{d}$ & \\
\hline NC100\%RCA & & $0.75^{d}$ & $206.25^{*}$ & $250^{d}$ & & & $998^{d}$ & $730^{d}$ \\
\hline NC75\%RMA & & $0.75^{d}$ & $206.25^{*}$ & $250^{d}$ & & $182^{d}$ & $998^{d}$ & \\
\hline NC100\%RCA-100\%RGC & & $0.75^{\mathrm{d}}$ & $206.25^{*}$ & & $250^{d}$ & & $998^{d}$ & $730^{d}$ \\
\hline NC75\%RMA-100\%RGC & & $0.75^{d}$ & $206.25^{*}$ & & $250^{d}$ & $182^{d}$ & $998^{d}$ & \\
\hline
\end{tabular}

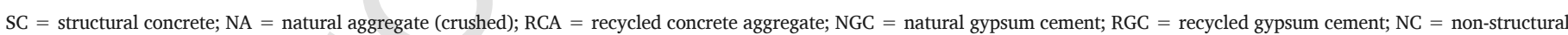
concrete; RMA = recycled mixed aggregate.

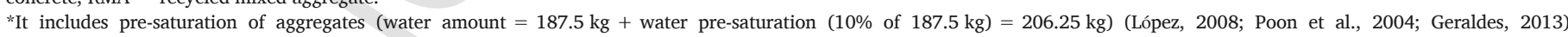
$\mathrm{NCA}=$ natural coarse aggregate, $\mathrm{NFA}=$ natural fine aggregate, $\mathrm{RCCA}=$ recycled concrete coarse aggregate, RMCA $=$ recycled mixed coarse aggregate

a Matias et al. (2013).

b Sánchez de Juan (2004).

c López (2008).

d Sánchez de Juan et al. (2011).

e Alaejos (2008).

substitution of natural coarse aggregate for recycled aggregate, even if the characteristics of the hardened concrete are affected. After this limit, the values of these characteristics decrease. The decrease becomes more notable as the percentage of substitution increases. In ad- dition, according to Appendix 18 "Non-structural concrete" of the Instruction of Structural Concrete, EHE-08 (Spain), up to 100\% of recycled coarse aggregates from concrete can be used. 


\subsection{Environmental criteria: life cycle assessment (LCA) methodology}

\subsubsection{Definition of goal and scope}

The aim of the LCA was to assess the environmental impacts of primary and secondary production of structural and non-structural concrete. The functional unit used for the concrete was $1 \mathrm{~m}^{3}$. This unit also was chosen in other similar studies, such as Kleijer et al. (2017).

The life cycle considered for concrete production is shown in Fig. 2.

Spain was chosen as the field of study. We considered that gypsum and aggregate mines were located near the plant to obtain natural gypsum (NG) and natural aggregate (NA). We only considered internal transport in the production of NG and NA. For RG and RA, we assumed that the source of waste was the centre of Barcelona.

The transport scenarios discussed in this study are presented in Table 2. The distances were calculated from the number of facilities in Catalonia: 114 aggregate quarries (Gremi d'Àrids de Catalunya, 2015), 150 concrete plants (ANEFHOP, 2015), 55 recycling plants (ARC, 2015), 10 gypsum quarries (Ministry of Industry Energy and Tourism, 2015) and 6 cement plants (Ciment Catalá, 2015). We also took into account the distribution of these facilities throughout Catalonia (ARC, 2015).

\subsubsection{System boundary and life cycle inventory}

Fig. 3 shows the system boundaries of gypsum, cement and aggregates included in concrete production. The system boundaries of concrete are also shown.

Primary data were obtained from interviews with companies and organizations in Spain, such as the Ministry of Industry, Energy and Tourism and the Association of Aggregates of Catalonia. Direct contact with 45 companies and national agencies was established. These data were supplemented with the Ecoinvent v 2.2 database, and were adapted to the Spanish context.

2.2.2.1. Cement : Ordinary Portland cement (CEM I) with $95 \%$ clinker and $5 \%$ gypsum was evaluated. In the recycled gypsum cement, recycled gypsum was used instead of natural gypsum.

Data on raw materials (with the exception of gypsum), infrastructure and energy consumption in the cement production process were obtained from the Ecoinvent database. The gypsum recycling process is that used in cement production, including the recycling of waste paper from the plasterboard. Gypsum waste is transported to the recycling plant where it is crushed and separated from the paper. Of the total weight of collected gypsum waste, $5 \%$ is paper from plasterboard (Suárez et al., 2016).

The consumption of diesel in the recycling plant, which is used in the crushing and separation of gypsum and paper, was obtained from the energy used to recycle gypsum in a plant with $65 \%-80 \%$ operating efficiency. The diesel consumption corresponds to $0.036 \mathrm{MJ} / \mathrm{kg}$ (GRI, 2015). The average distance from the recycling plants to the centre of Barcelona is $50 \mathrm{~km}$, since this is the maximum distance that waste will be transported, according to the number and distribution of plants throughout Catalonia (ARC, 2015).

2.2.2.2. Aggregate and concrete: In this system, we included recycled aggregate (recycled concrete aggregate, RCA; recycled mixed aggregate, RMA) in addition to NA. For the recycled aggregate (RA), we considered a transport distance from the centre of Barcelona to the recycling plant of $7 \mathrm{~km}$, according to the Catalan Waste Agency (ARC, 2015).

According to information supplied by the recycling plants that we visited, diesel consumption during separation of steel for the production of recycled concrete aggregate (RCA) is $0.0018 \mathrm{MJ} / \mathrm{kg}$. Once the concrete has been separated from the metal, it passes through the crusher machines.

Diesel consumption during the transport, crushing and grading of the material corresponds to $0.014 \mathrm{MJ} / \mathrm{kg}$, according to the recycling plants of Catalonia (2010-2013) and Mercante et al. (2010).

Thus, total consumption of diesel during the aggregate recycling process is $0.015 \mathrm{MJ} / \mathrm{kg}$. Electricity consumption in offices and workshops is equal to $1.02 \mathrm{kWh} / \mathrm{t}$ (recycling plants in Spain, 2009-2013) and electricity consumption for crushing is equivalent to $0.975 \mathrm{kWh} / \mathrm{t}$ (Mercante et al., 2010).

The composition of the recycled mixed aggregate (RMA) can be highly variable. However, we considered that the waste consists of more than $70 \%$ concrete and less than $30 \%$ ceramic. This type of waste can be used to obtain "Type 2" mixed aggregates according to German regulation: DIN 4226-100, 2002, which can reach an acceptable strength in recycled concrete. In this case, $0.028 \mathrm{~kg}$ of steel are produced per $1 \mathrm{~kg}$ of mixed aggregate produced according to the proportions given by Zazurca Ruiz-Cerdà (2012) and BEDEC (2015).

Table 3 shows the inputs and outputs of the recycled concrete. In the production of concrete, an equal transport distance is considered for original and secondary raw materials.

In the case of the transport of solid waste generated in the production of concrete, in all the alternatives we considered a distance of

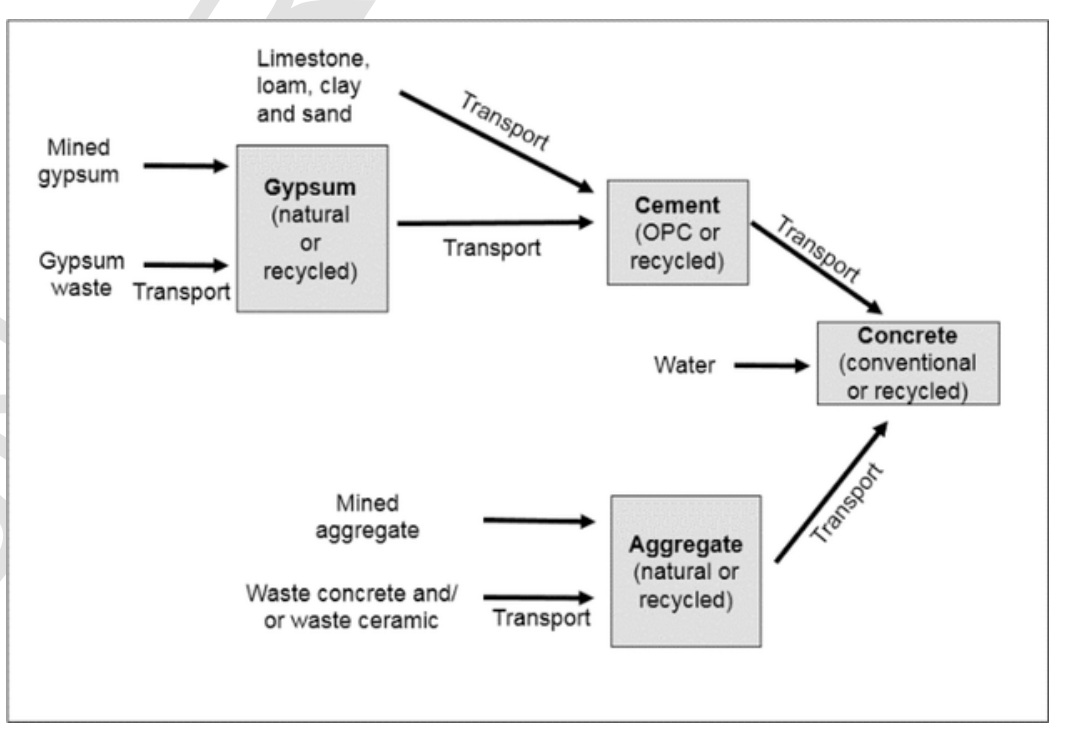

Fig. 2. Life cycle of concrete. 
Table 2

Transport scenarios.

\begin{tabular}{llll}
\hline Installation & Transport distance $(\mathrm{km})$ & \\
\hline Plant concrete & Cement & NA & RA \\
& 15 & 5 & 7 \\
Plant cement & NG & & \\
& 15 & RG & \\
\hline
\end{tabular}

$17 \mathrm{~km}$ to the inert landfill and $21 \mathrm{~km}$ to the municipal landfill (ARC, 2015).

\subsubsection{Life cycle impact assessment}

The categories were chosen taking into account the latest scientific consensus, expressed in CEN/TC350 (2012): recommendations about the impact categories to be evaluated to undertake LCA studies in buildings. Other LCA studies related with the management of CDW (see Table 4) were also taken into account.

Impact $2002+$ was chosen as a method of impact assessment, as it is best suited to all categories of the impacts that were selected, and can also evaluate all the categories without using another method of evaluation.

\subsection{Economic criteria}

The economic criteria were evaluated taking into account production costs for the various products obtained. The method used to calculate the economic cost was based on an economic study of building materials carried out by Tošić et al. (2015). The aim was to find the approximate cost as a reference for each of the alternative ways of producing a material which, in turn, allows comparisons to be made.

The reference cost of aggregates, cement and concrete was calculated by adding the cost of producing each material and the cost of the management of waste generated during the process, see Eq. (1)-(3).

$$
R e f C=E c+C m
$$

$$
\begin{aligned}
& E c=R e C+C t \\
& C t=D t * C d
\end{aligned}
$$

RefC $=$ reference cost $(\epsilon / t)$

$E c=$ production cost $(\epsilon / t)$

$\mathrm{Cm}=$ cost of management $(\epsilon / t)$

$\operatorname{ReC}=$ recycling cost $(\epsilon / t)$

$C t=$ cost of transporting the waste $(\epsilon / t)$

$D t=$ distance traveled $(m / t)$

$C d=$ costs per distance $(\epsilon / \mathrm{km})$

The cost of production of the various materials was determined on the basis of the cost obtained from companies, organizations and recycling plants consulted in Spain. Data were gathered in different years from different companies or plants that have a similar production capacity.

These data were complemented by BEDEC (2015), which also refers to the cost of production of the material.

\subsection{VIKOR method: multi-criteria analysis}

To choose the best concrete option according to environmental and economic criteria, a multi-criteria decision-making method was used, called the VIKOR method. This method focuses on prioritizing and selecting a set of alternatives when there are conflicting views. It introduces the multi-hierarchical index, based on the particular measure of "closeness" to the "ideal" solution (Opricovic, 1998; Opricovic and Tzeng, 2007).

The VIKOR method was employed because it has been used in scientific studies in the field of environment and materials engineering with very good results, for example, Civic and Vucijak (2014), Tošić et al. (2015) and Suganthi et al. (2015). In addition, this method allows quantitative and qualitative analysis methods to be combined, to improve the results of the environmental and economic evaluation. Due to the simplicity of its algorithm, modifications can be made to adapt the method to a specific case, and qualifying criteria can be established to assign relative importance to them during the decision-making process.

Nevertheless, before using the VIKOR method, the results of the evaluation of life cycle impacts were normalized to obtain relevant indexes.

To carry out the normalization, the impact categories were grouped into two criteria functions (F1 and F2), taking into account the classification made in the Impact $2002+$ method (SIMAPRO, 2008). Thus, an index (F1) was obtained, corresponding to categories related to human health (RI, RO, C and NC) and another index (F2) was obtained with categories related to the quality of the ecosystem, climate change and resource consumption (E, A, OD, GWg, NRE, LO and ME).

Eq. (4) was used to perform the normalization.

$$
f=\sum_{i c=1}^{n} w\left(f^{*}{ }_{i c}-f_{i c j}\right) /\left(f^{*}{ }_{i c}-f-{ }_{i c}\right)
$$

In the normalization, a weighting factor $(w)$ was used to assign equal weight to all the assessed impact categories. This weighting factor has been used by authors such as Álvarez del Castillo (2014) for waste management issues. On this basis, and taking into account the study by Tošić et al. (2015), a factor of 0.25 was used for midpoint categories related to human health, and a factor of 0.14 for midpoint categories related to the ecosystem, climate change and resource consumption.

The VIKOR method was then applied. Taking the identification of best and worst values for each criterion function, the $S_{j}$ and $R_{j}$ values were determined $(j=1,2 \ldots, \mathrm{J})$ by Eqs. (5) and (6).

$S_{j}=\sum_{i=1}^{n} w i\left(f^{*}{ }_{i}-f_{i j}\right) /\left(f^{*}{ }_{i}-f{ }_{i}\right)$

$R_{j}=\max _{i}\left(w i\left(f^{*}{ }_{i}-f_{i j}\right) /\left(f^{*}{ }_{i}-f^{-}{ }_{i}\right)\right)$

Where:

$j=$ alternative

$n=$ number of criteria

$S_{j}=$ distances of alternatives to the best solution

$R_{j}=$ distance between the alternatives and the worst solution

$w i=$ weights of criteria, expressing the preference of decision makers as relative importance of the criteria.

A sensitivity analysis was conducted to evaluate the influence of criteria weights on the results. Three criteria of classification were chosen: equal importance: all criteria (F1, F2 and F3) are equally important; environmental advantage: criteria F1 and F2 are given a 2:1 advantage compared to criteria F3; economic advantage: criteria F3 is given a 2:1 advantage over criteria F1 and F2. 


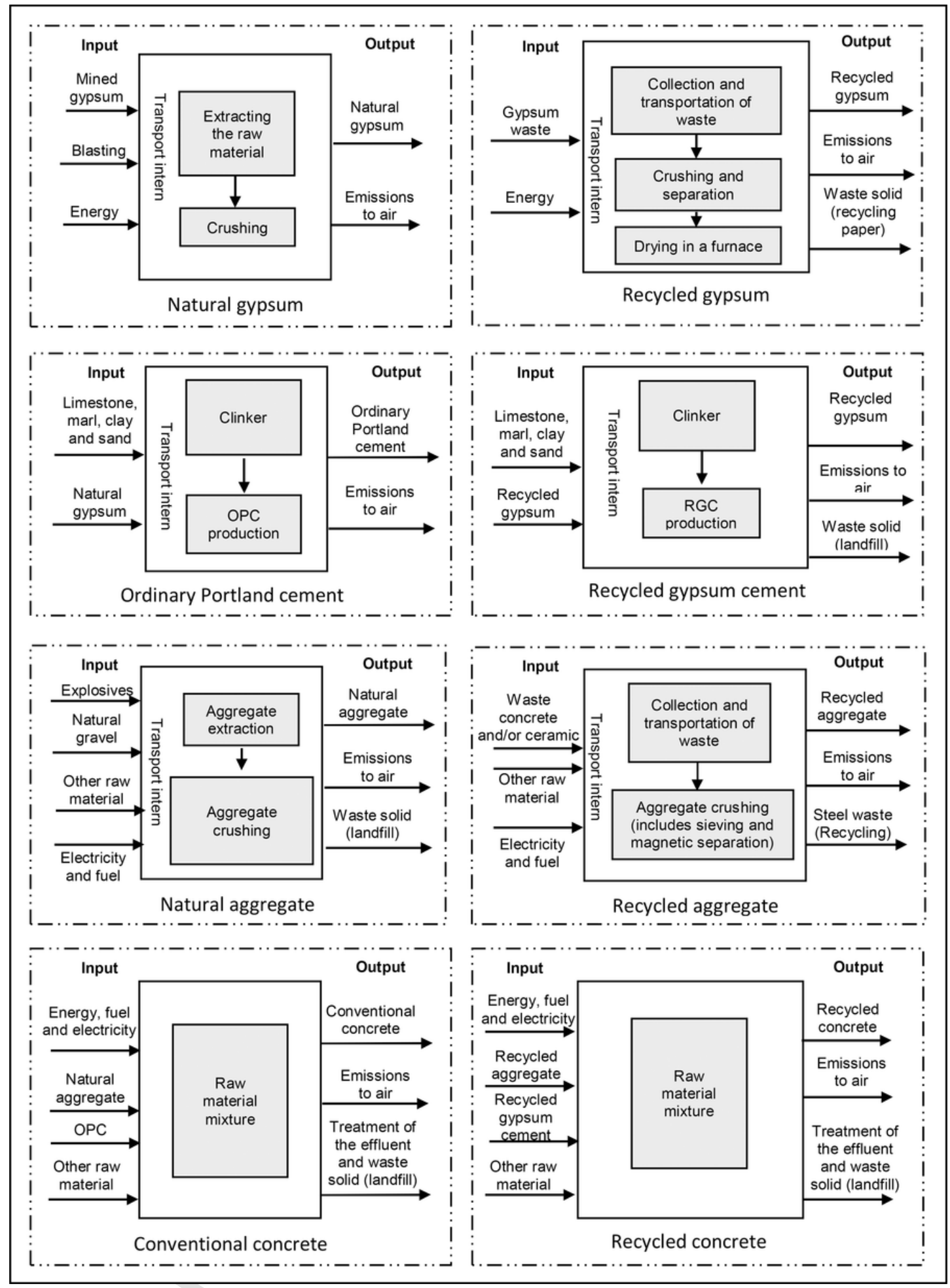

Fig. 3. The system boundaries of gypsum, cement, aggregate and concrete. 
Table 3

Inputs and outputs of recycled concrete (SC and NC).

\begin{tabular}{|c|c|c|c|}
\hline \multicolumn{4}{|l|}{ Inputs } \\
\hline Basic process & Unit & Amount & Reference \\
\hline Production plant infrastructure & $\mathrm{p}$ & $4.57 \mathrm{E}-07$ & Ecoinvent v2.2 \\
\hline Diesel (machinery) & MJ & $2.27 \mathrm{E}+01$ & Ecoinvent v2.2 \\
\hline Electricity & $\mathrm{kWh}$ & $4.36 \mathrm{E}+00$ & Ecoinvent v2.2 \\
\hline Aggregate(SC)/aggregate(NC) & $\mathrm{kg}$ & $\begin{array}{l}2.25 \mathrm{E}+03 / \\
1.98 \mathrm{E}+03\end{array}$ & $\begin{array}{l}\text { Ministry of Industry Energy and Tourism (2015); AFA (2014); Gremi d'Àrids de Catalunya } \\
\text { (2015); ARC (2015); Recycling plants (2010-2014); Mercante et al. (2010); Zazurca Ruiz- } \\
\text { Cerdà (2012); BEDEC (2015) and Ecoinvent v2.2. }\end{array}$ \\
\hline $\begin{array}{l}\text { Fuel oil (heavy) in industrial } \\
\text { furnace }\end{array}$ & MJ & $3.09 E+00$ & Ecoinvent v2.2 \\
\hline $\begin{array}{l}\text { Fuel oil (light) in industrial } \\
\text { furnace }\end{array}$ & $\mathrm{kg}$ & $1.33 \mathrm{E}+01$ & Ecoinvent v2.2 \\
\hline Lubricant oil & $\mathrm{kg}$ & $1.19 \mathrm{E}-02$ & Ecoinvent v2.2 \\
\hline Natural gas & MJ & $1.16 \mathrm{E}+00$ & Ecoinvent v2.2 \\
\hline Cement(SC)/cement(NC) & $\mathrm{kg}$ & $\begin{array}{l}3.75 \mathrm{E}+02 / \\
2.50 \mathrm{E}+02\end{array}$ & $\begin{array}{l}\text { Ministry of Industry Energy and Tourism (2015); Spanish cement companies (2009-2011); } \\
\text { López (2008) and Ecoinvent v2.2. }\end{array}$ \\
\hline Wear parts (steel) & $\mathrm{kg}$ & $2.38 \mathrm{E}-02$ & Ecoinvent v2.2 \\
\hline Wear parts (synthetic rubber) & $\mathrm{kg}$ & $7.13 \mathrm{E}-03$ & Ecoinvent v2.2 \\
\hline Water(SC)/water(NC) & $\mathrm{kg}$ & $\begin{array}{l}1.88 \mathrm{E}+02 / \\
2.06 \mathrm{E}+02\end{array}$ & Ecoinvent v2.2 \\
\hline \multicolumn{4}{|l|}{ Outputs } \\
\hline Heat & MJ & $1.57 \mathrm{E}+01$ & Ecoinvent v2.2 \\
\hline Concrete waste disposal & $\mathrm{kg}$ & $1.69 \mathrm{E}+01$ & Ecoinvent v2.2 \\
\hline Solid waste disposal & $\mathrm{kg}$ & $9.51 \mathrm{E}-02$ & Ecoinvent v2.2 \\
\hline Effluent treatment & $\mathrm{m}^{3}$ & 1.43E-02 & Ecoinvent v2.2 \\
\hline
\end{tabular}

Table 4

Impact categories used in studies related.

\begin{tabular}{|c|c|c|c|c|c|c|c|c|c|c|}
\hline Authors & GWg & OD & A & E & RO & ME & $\mathrm{C}-\mathrm{NC}$ & NRE & RI & LO \\
\hline Tošić et al. (2015) & $\mathrm{X}$ & & $\mathrm{X}$ & $\mathrm{X}$ & $\mathrm{X}$ & $\mathrm{X}$ & & $\mathrm{X}$ & & \\
\hline Álvarez (2010) & $\mathrm{X}$ & & $\mathrm{X}$ & $\mathrm{X}$ & $\mathrm{X}$ & & $\mathrm{X}$ & & $\mathrm{X}$ & $\mathrm{X}$ \\
\hline Kofoworola and Gheewala (2009) & $\mathrm{X}$ & & $\mathrm{X}$ & & $\mathrm{X}$ & & & & & \\
\hline Blengini and Di Carlo (2010) & $\mathrm{X}$ & $\mathrm{X}$ & $\mathrm{X}$ & $\mathrm{X}$ & $\mathrm{X}$ & & & & & \\
\hline Birgisdóttir et al. (2006) & $\mathrm{X}$ & & $\mathrm{X}$ & & & & & & & \\
\hline Castell et al. (2013) & $\mathrm{X}$ & $\mathrm{X}$ & $\mathrm{X}$ & $\mathrm{X}$ & & & & $\mathrm{X}$ & $\mathrm{X}$ & $\mathrm{X}$ \\
\hline Rincón et al. (2014) & $\mathrm{X}$ & $\mathrm{X}$ & $\mathrm{X}$ & $\mathrm{X}$ & & & & $\mathrm{X}$ & $\mathrm{X}$ & $\mathrm{X}$ \\
\hline Lasvaux et al. (2014) & $\mathrm{X}$ & & & & $\mathrm{X}$ & & & & & \\
\hline Li et al. (2010) & $\mathrm{X}$ & $\mathrm{X}$ & $\mathrm{X}$ & $\mathrm{X}$ & & & & $\mathrm{X}$ & $\mathrm{X}$ & \\
\hline CEN/TC350 (2012) & $\mathrm{X}$ & $\mathrm{X}$ & $\mathrm{X}$ & $\mathrm{x}$ & $\mathrm{X}$ & $\mathrm{X}$ & & & & \\
\hline Jolliet et al. (2014) & $\mathrm{X}$ & $<$ & $\mathrm{X}$ & $\mathrm{x}$ & & & $\mathrm{X}$ & $\mathrm{X}$ & $\mathrm{X}$ & $\mathrm{X}$ \\
\hline Zabalza Bribián (2012) & $\mathrm{X}$ & $\mathrm{X}$ & $\mathrm{X}$ & $\mathrm{x}$ & $\mathrm{X}$ & $\mathrm{X}$ & & & & \\
\hline Benveniste et al. (2011) & $\mathrm{X}$ & $\mathrm{X}$ & $\mathrm{X}$ & $\mathrm{X}$ & $\mathrm{X}$ & $\mathrm{X}$ & & $\mathrm{X}$ & & \\
\hline
\end{tabular}

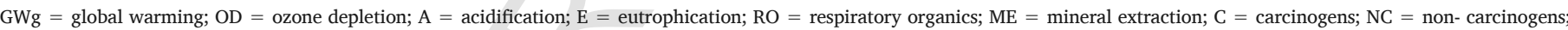
$\mathrm{NRE}=$ non-renewable energy; RI = respiratory inorganics; $\mathrm{LO}=$ land occupation

Subsequently Q was calculated using Eq. (7)

$$
\begin{aligned}
Q_{j}= & v\left(S_{j}-S^{*}\right) /\left(S^{-}-S^{*}\right) \\
& +(1-v)\left(R_{j}-R^{*}\right) /\left(R^{-}-R^{*}\right)
\end{aligned}
$$

$$
S^{*}=\min _{j} S_{j}, S^{-}=\max _{j} S_{j}
$$

$$
R^{*}=\min _{j} R_{j}, R^{-}=\max _{j} R_{j}
$$

The value of 0.5 was adopted for $v$. This gives equal weight to $S_{j}$ and $R_{j}$ and avoids giving preference to one of them.

Once the VIKOR method had been applied, the alternatives were organized. The values of $\mathrm{S}, \mathrm{R}$ and $\mathrm{Q}$ were ranked in descending order, considering that the optimal alternative was the closest to 0 and the worst option was the nearest to 1 . The results were expressed as three ordered lists, but the results of list $\mathrm{Q}$ were considered in the choice of the optimal alternative for each of the criteria.

One alternative is proposed if conditions a) and b) are met.

$Q(a)^{\mathrm{e}} ;-Q(a)^{\prime} \geq D Q$
${ }^{D} Q=\min (1 /(j-1) ; 0.25)$

Where:

a" = alternative in second position of $\mathrm{Q}$.

b) Alternative á should also be the best in lists S and/or R.

If conditions a) and b) are not met, multiple alternatives are proposed:

1. Alternatives a' and a" if only condition b) is not satisfied. 
2. Alternatives $a, a^{\prime \prime} \ldots a^{\wedge}(M)$ if condition a) is not satisfied; and (M) is determined by Eq. (8) for maximum $\mathrm{M}$.

$$
Q(a)^{M}-Q(a)^{\prime}<D Q
$$

\section{Results and discussion}

\subsection{Structural concrete}

Fig. 4 shows the differences between the types of structural concrete studied. If each impact value is represented on a relative scale from $0 \%$ to $100 \%$, it is clear that SC100\%NA had the greatest impact in all categories, except carcinogenic and non-carcinogenic effects. This is explained by the fact that NA has a greater impact than RCA, due to the use of blasting NA, mine infrastructure, and increased fuel consumption.

The fact that concrete with NA had a greater impact than concrete with RA is in agreement with results found by Tošić et al. (2015).

In all categories, apart from carcinogenic and non-carcinogenic effects, the impact of producing SC20\%RCA was lower than that of producing SC100\%NA. In the category of mineral extraction, SC20\%RCA led to savings because virgin aggregate does not have to be extracted when recycled aggregate is used. The savings are even greater in this category because steel waste from reinforced concrete is also recycled in the process of producing recycled aggregate. These results are in line with those found by Turk et al. (2015).

SC20\%RCA-100\%RGC had a lower impact than SC20\%RCA (Fig. 4). Negative values mean savings in the categories evaluated. In the category of mineral extraction, great savings ( $-93 \%$ ) were made when RCA was used. RGC also contributed to savings in this category, as ordinary Portland cement (OPC) does not have to be produced. The use of RG in cement was also found to contribute to a reduction in impacts in the other categories.

There were impacts on the carcinogenic and non-carcinogenic categories for the production of concrete with recycled aggregate, since the impacts of steel management (secondary steel production) on the process of obtaining recycled aggregate. However, it is important to note that in the production of secondary steel the extraction of original raw material is avoided, compared to the production of primary steel, where there is an impact by the extraction of the raw material.
In order to know the reference cost for each structural concrete alternative, the proportion of each material within the concrete (Table 1) and the execution cost of each material were taken into account separately.

So as to calculate the cost of production of the concrete - in which different raw materials are used - it was necessary to calculate separately the cost of raw materials that vary from one product to another, without forgetting, later, to include within the cost the rest of processes which remain similar in both productive processes. In this way, the economic differences between the production alternatives of concrete from original raw material or from recycled raw material were obtained (Table 5).

Because all the alternatives generate the same waste and all are treated the same treatment, the cost of management of these remains constant in all production systems.

The alternative SC100\%NA had the highest cost, due to the higher cost of NA than RCA. When SC20\%RCA and SC20\%RCA-100\%RGC were compared, it was observed that the use of RGC minimally contributed to lower costs than concrete containing OPC.

Finally, the results of the VIKOR method for structural concrete alternatives are shown in Table 6. This Table indicates that the alternative chosen as the best option for all classifications of the criteria is SC20\%RA-100\%RGC. The order of the alternatives was similar in all three ranking lists $(\mathrm{Q}, \mathrm{R}$ and $\mathrm{S})$.

\subsection{Non-structural concrete}

NC100\%NA had great impacts in all categories, except for carcinogenic and non-carcinogenic effects (Fig. 5). This is due to the fact that NA had a greater impact than RA in most categories evaluated. This statement is consistent with a study by Tošić et al. (2015). NC100\%NA had the least impact on the category of carcinogenic effects (8\%), because less carcinogenic substances were emitted to obtain NA than to obtain RA. The process of obtaining RA includes recycling steel from reinforced concrete, and the casting process in steel recycling leads to the emission of substances that can have carcinogenic effects on human health.

When concrete is produced by replacing all the natural coarse aggregate with recycled concrete aggregate (NC100\%RCA), the highest impact is in the categories of carcinogenic and non-carcinogenic effects (100\%) (due to the casting process for recycled steel), but greater savings are made in the category of mineral extraction $(-93 \%)$, because

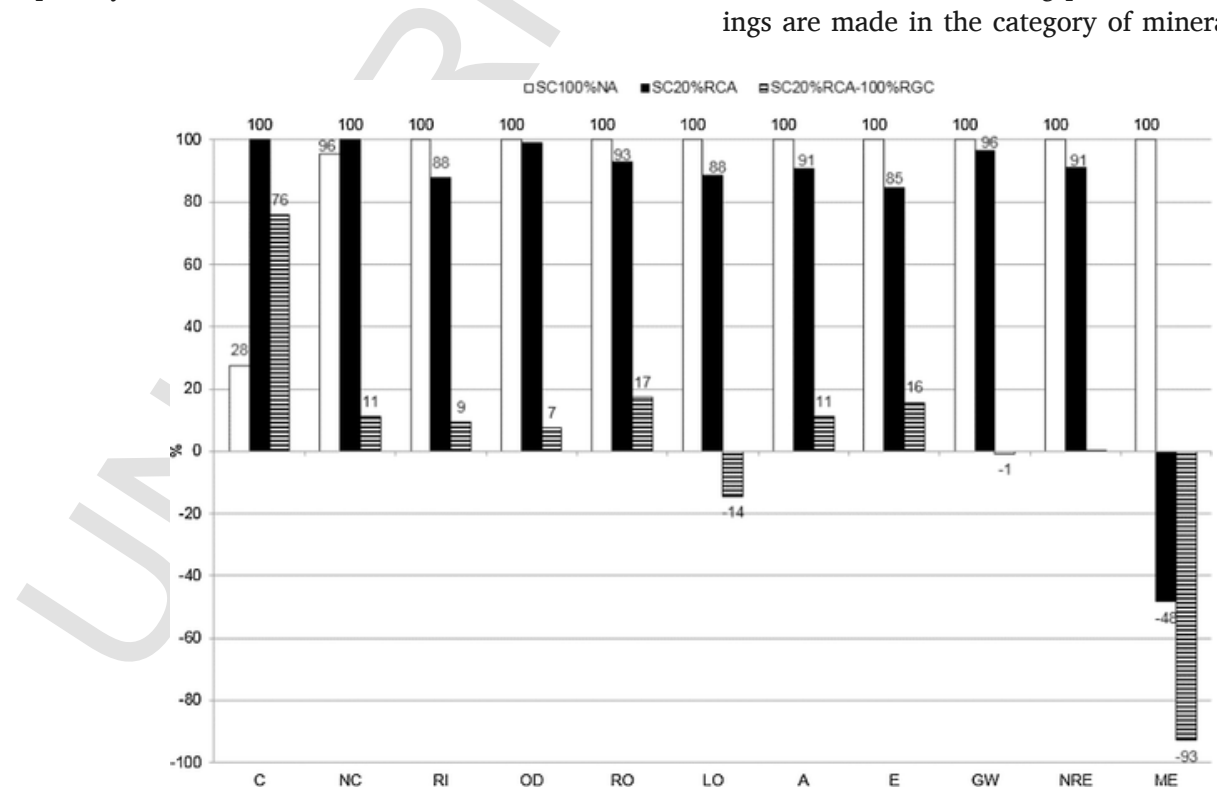

Fig. 4. Percentage contribution of different production alternatives to structural concrete. 
Table 5

Reference cost for each alternative production of structural concrete ${ }^{\mathrm{b}} \mathrm{Cm}=$ cost of waste management generated in the concrete production process $=$ (municipal waste disposal + inert waste disposal + wastewater treatment (water canon) $)=(1.95 \mathrm{E}-03$ $\left.€ / \mathrm{m}^{3}+9.64 \mathrm{E}-03 € / \mathrm{m}^{3}+1.10 \mathrm{E}-02 € / \mathrm{m}^{3}\right)=\left(2.28 \mathrm{E}-02 € / \mathrm{m}^{3}\right)$, according to company data (includes transport). ${ }^{\mathrm{C} E q}$. (1). The amount of material used or substituted in the mixtures according to the composition of Table 1 was taken into account and data obtained from companies, organizations in Spain. ${ }^{\mathrm{d} E q . ~(1)-(3) . ~ T h e ~ a m o u n t ~ o f ~ m a t e r i a l ~}$ used or substituted in the mixtures according to the composition of Table 1 was taken into account and data obtained from companies, organizations and recycling plants consulted.

\begin{tabular}{lll}
\hline Alternatives & Method of obtaining the reference cost & $\begin{array}{c}\text { Total } \\
\left(€ / \mathrm{m}^{3}\right)\end{array}$ \\
\hline SC100\%NA & $\left.\left(84.99 € / \mathrm{m}^{3 \mathrm{a}}\right)\right)+(\mathrm{cm})^{\mathrm{b}}$ & 85.01 \\
SC20\%RCA & $\left(84.73 € / \mathrm{m}^{3 \mathrm{a}}\right)+(\mathrm{cm})^{\mathrm{b}}$ & 84.75 \\
SC20\%RCA-100\%RGC & $($ Cost of SC20\%RCA $(84.75$ & 84.58 \\
& $\left.\left.€ / \mathrm{m}^{3}\right)\right)-($ Cost of CPO $(44.63$ & \\
& $\left.€ / \mathrm{m}^{3 \mathrm{c}}\right)+\left(\right.$ Cost of RGC $\left(44.46 € / \mathrm{m}^{3 \mathrm{~d}}\right)$ & \\
\hline
\end{tabular}

aBEDEC (2015).

${ }^{\mathrm{b}} \mathrm{Cm}=$ cost of waste management generated in the concrete production process $=$ (municipal waste disposal + inert waste disposal + wastewater treatment $($ water canon $))=\left(1.95 \mathrm{E}-03 € / \mathrm{m}^{3}+9.64 \mathrm{E}-03 € / \mathrm{m}^{3}+1.10 \mathrm{E}-02 € / \mathrm{m}^{3}\right)=(2.28 \mathrm{E}-02$ $€ / \mathrm{m}^{3}$ ), according to company data (includes transport).

Table 6

List of values $\mathrm{S}, \mathrm{R}$ and $\mathrm{Q}$ calculated in the production of structural concrete.

\begin{tabular}{lllll}
\hline $\begin{array}{l}\text { Classification } \\
\text { criteria }\end{array}$ & Alternatives & $\mathrm{Qj}$ & $\mathrm{Sj}$ & $\mathrm{Rj}$ \\
\hline $\begin{array}{l}\text { Equal } \\
\text { importance }\end{array}$ & SC20\%RCA-100\%RGC & 0.00 & 0.00 & 0.00 \\
& SC20\%RCA & 0.90 & 0.73 & 0.33 \\
& SC100\%NA & 1.00 & 0.90 & 0.33 \\
$\begin{array}{l}\text { Environmental } \\
\text { advantage }\end{array}$ & SC20\%RCA-100\%RGC & 0.00 & 0.00 & 0.00 \\
& SC20\%RCA & 0.95 & 0.80 & 0.40 \\
& SC100\%NA & 1.00 & 0.89 & 0.40 \\
$\begin{array}{l}\text { Economical } \\
\text { advantage }\end{array}$ & SC20\%RCA-100\%RGC & 0.00 & 0.00 & 0.00 \\
& SC20\%RCA & 0.60 & 0.65 & 0.20 \\
& SC100\%NA & 1.00 & 0.93 & 0.50 \\
\hline
\end{tabular}

recycled steel from reinforced concrete also replaces the extraction of original raw material.

NC100\%RCA-100\%RGC had lower impacts in all categories than the same concrete containing OPC (NC100\%RCA) (Fig. 5).

A comparison of NC75\%RMA with NC100\%NA (Fig. 5) showed that NC75\%RMA had a greater impact in the categories of carcinogenic and non-carcinogenic effects. In the other categories, it had less impact than NC100\%NA or led to savings, due to the use of RA. It could be said that, in the production of concrete, RA contributes to impacts on the categories of carcinogenic and non-carcinogenic effects, and reduces the impact on other categories evaluated. It also generates savings in the category of mineral extraction. Table 7 shows the results of the characterization of structural and non-structural concrete.

Table 8 shows the calculation results obtained for the reference cost of each non-structural concrete alternative. The alternative with the greatest cost is NC100\%NA, whilst the alternative NC100\%RCA-100\%RGC had lower costs. This is because of the higher cost of NA than RCA, which was also confirmed by Tam (2008), Coelho and De Brito (2013a) and Coelho and De Brito (2013b), and the lower cost of RGC than OPC, as evidenced by the WRAP (2008) test.

If we compare concretes that have the same compressive strength but different types and proportions of aggregates (NC100\%NA, NC100\%RCA and NC75\%RMA), NC100\%RCA has the lowest cost, and the NC75\%RMA alternative has an intermediate cost. This is because the RMA alternative also contains NA, and this increases the overall cost of the concrete. However, it is still below the cost of NC100\%NA.

As in structural concrete, the use of RGC minimally reduces the production cost of the concrete compared to the use of OPC.

Finally, the results of the VIKOR method for non-structural concrete alternatives are shown in Table 9. The alternatives NC100\%RCA-100\%RGC and NC75\%RMA-100\%RGC are proposed as the best options. In the list of $\mathrm{Q}$ and $\mathrm{R}$, the order of high to worst alternative option is: $\mathrm{A} 4, \mathrm{~A} 5, \mathrm{~A} 3, \mathrm{~A} 2$ and $\mathrm{A} 1$, when equal importance is applied to all criteria or an advantage is given to the environmental aspect. When priority is given to the economic aspect, NC100\%RCA is third in the list of Q and the alternative NC75\%RMA is fourth.

However, for all classifications of the criteria in the list of $S$, the alternatives are in the order: A4, A5, A2, A3 and A1. Nevertheless, for the purposes of choosing the best option and the final hierarchical list of alternatives, the results of $\mathrm{Q}$ are taken into account, since, as men-

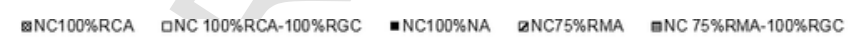

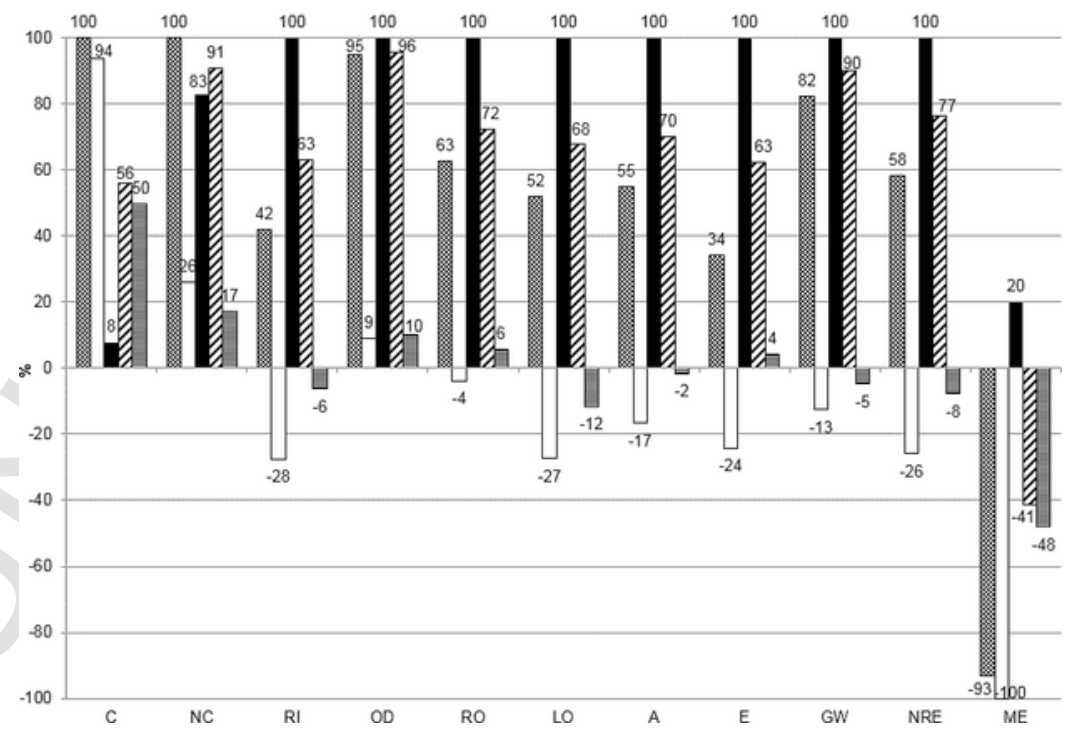

Fig. 5. Percentage contribution of production alternatives for non-structural concrete. 
Table 7

Results of the characterization of structural and non-structural concrete.

\begin{tabular}{|c|c|c|c|c|c|c|c|c|c|}
\hline Categories & Unit & SC $100 \% \mathrm{NA}$ & SC $20 \%$ RCA & SC $20 \%$ RCA- $100 \%$ RGC & NC $100 \%$ NA & NC $100 \%$ RCA & NC 75\%RMA & NC $100 \%$ RCA- $100 \%$ RGC & NC 75\%RMA-100\%RGC \\
\hline $\mathrm{C}$ & $\mathrm{kg} \mathrm{C}_{2} \mathrm{H}_{3} \mathrm{Cl}$ eq & 9.33E-01 & $3.38 \mathrm{E}+00$ & $2.57 \mathrm{E}+00$ & $6.84 \mathrm{E}-01$ & $8.62 \mathrm{E}+00$ & $4.84 \mathrm{E}+00$ & $8.08 \mathrm{E}+00$ & $4.30 \mathrm{E}+00$ \\
\hline $\mathrm{NC}$ & $\mathrm{kg} \mathrm{C}_{2} \mathrm{H}_{3} \mathrm{Cl}$ eq & $3.47 \mathrm{E}+00$ & $3.63 \mathrm{E}+00$ & 4.08E-01 & $2.40 \mathrm{E}+00$ & $2.90 \mathrm{E}+00$ & $2.64 \mathrm{E}+00$ & $7.61 \mathrm{E}-01$ & 4.99E-01 \\
\hline RI & kg PM 2.5 eq & $1.28 \mathrm{E}-01$ & $1.12 \mathrm{E}-01$ & $1.19 \mathrm{E}-02$ & $9.58 \mathrm{E}-02$ & 4.02E-02 & $6.06 \mathrm{E}-02$ & $-2.64 \mathrm{E}-02$ & $-5.98 \mathrm{E}-03$ \\
\hline $\mathrm{OD}$ & kg CFC-11 eq & $1.05 \mathrm{E}-05$ & $1.04 \mathrm{E}-05$ & $7.85 \mathrm{E}-07$ & $7.48 \mathrm{E}-06$ & $7.08 \mathrm{E}-06$ & $7.15 \mathrm{E}-06$ & $6.82 \mathrm{E}-07$ & 7.53E-07 \\
\hline RO & $\mathrm{kg} \mathrm{C}_{2} \mathrm{H}_{4}$ eq & $5.00 \mathrm{E}-02$ & $4.64 \mathrm{E}-02$ & $8.58 \mathrm{E}-03$ & $3.78 \mathrm{E}-02$ & $2.38 \mathrm{E}-02$ & $2.73 \mathrm{E}-02$ & $-1.42 \mathrm{E}-03$ & $2.17 \mathrm{E}-03$ \\
\hline LO & m2org.arable & $8.45 \mathrm{E}-01$ & $7.48 \mathrm{E}-01$ & $-1.21 \mathrm{E}-01$ & $7.30 \mathrm{E}-01$ & $3.80 \mathrm{E}-01$ & $4.94 \mathrm{E}-01$ & $-2.00 \mathrm{E}-01$ & $-8.49 \mathrm{E}-02$ \\
\hline A & $\mathrm{kg} \mathrm{SO}_{2}$ eq & 6.93E-01 & $6.30 \mathrm{E}-01$ & 7.62E-02 & 5.14E-01 & $2.83 \mathrm{E}-01$ & $3.60 \mathrm{E}-01$ & $-8.56 \mathrm{E}-02$ & $-8.43 \mathrm{E}-03$ \\
\hline $\mathrm{E}$ & $\mathrm{kg} \mathrm{PO}_{4} \mathrm{p}$-lim & $1.13 \mathrm{E}-02$ & $9.51 \mathrm{E}-03$ & $1.76 \mathrm{E}-03$ & $8.87 \mathrm{E}-03$ & 3.02E-03 & $5.54 \mathrm{E}-03$ & $-2.14 \mathrm{E}-03$ & $3.82 \mathrm{E}-04$ \\
\hline GWg & $\mathrm{kg} \mathrm{CO}_{2}$ eq & $3.23 E+02$ & $3.12 \mathrm{E}+02$ & $-1.94 \mathrm{E}+00$ & $2.20 \mathrm{E}+02$ & $1.81 \mathrm{E}+02$ & $1.98 \mathrm{E}+02$ & $-2.75 E+01$ & $-1.03 \mathrm{E}+01$ \\
\hline NRE & MJ primaria & $1.61 E+03$ & $1.46 \mathrm{E}+03$ & $7.52 \mathrm{E}+00$ & $1.15 E+03$ & $6.72 \mathrm{E}+02$ & $8.82 \mathrm{E}+02$ & $-2.98 \mathrm{E}+02$ & $-8.78 \mathrm{E}+01$ \\
\hline ME & MJ surplus & $1.46 \mathrm{E}+00$ & $-7.07 \mathrm{E}-01$ & $-1.36 \mathrm{E}+00$ & $1.26 \mathrm{E}+00$ & $-5.86 \mathrm{E}+00$ & $-2.59 \mathrm{E}+00$ & $-6.30 \mathrm{E}+00$ & $-3.02 \mathrm{E}+00$ \\
\hline
\end{tabular}


Table 8

Reference cost of each of the alternative production for non-structural concrete.

\begin{tabular}{|c|c|c|}
\hline Alternatives & $\begin{array}{l}\text { Method of obtaining the reference } \\
\text { cost }\end{array}$ & $\begin{array}{l}\text { Total } \\
\left(€ / \mathrm{m}^{3}\right)\end{array}$ \\
\hline NC100\%NA & $\left(60.49 € / \mathrm{m}^{3 \mathrm{a}}\right)+\mathrm{cm}$ & 60.51 \\
\hline NC100\%RCA & $\begin{array}{l}\text { (Cost of NC100\%NA }(60.51 \\
\left.\left.€ / \mathrm{m}^{3}\right)\right)-\left(\left(\mathrm{CW}_{\mathrm{NA}}+\mathrm{CNA}\right)(35.6\right. \\
\left.\left.€ / \mathrm{m}^{3 \mathrm{~b}}\right)\right)+\left(\left(\mathrm{CW}_{\mathrm{ACp}}+\mathrm{CACp}\right)(21.75\right. \\
\left.\left.€ / \mathrm{m}^{3 \mathrm{c}}\right)\right)\end{array}$ & 46.66 \\
\hline NC75\%RMA & $\begin{array}{l}\text { (Cost of NC100\%RA ( } 46.66 \\
\left.\left.€ / \mathrm{m}^{3}\right)\right)-(\text { CACp }(3.64 \\
\left.\left.€ / \mathrm{m}^{3 \mathrm{~b}}\right)\right)+((\mathrm{CNA}+\mathrm{CMAp})(5.56 \\
\left.\left.€ / \mathrm{m}^{3 \mathrm{c}}\right)\right)\end{array}$ & 48.58 \\
\hline NC100\%RCA-100\%RGC & $\begin{array}{l}\text { (Cost of NC100\%RCA }(46.66 \\
\left.€ / \mathrm{m}^{3}\right)-(\text { Cost of CPO }(29.63 \\
\left.\left.€ / \mathrm{m}^{3 b}\right)\right)+(\text { Cost of RGC }(29.52 \\
\left.\left.€ / \mathrm{m}^{3 c}\right)\right)\end{array}$ & 46.55 \\
\hline NC75\%RMA-100\%RGC & $\begin{array}{l}\text { (Cost of NC75\%RMA }(48.58 \\
\left.\left.€ / \mathrm{m}^{3}\right)\right)-(\text { Cost of CPO }(29.63 \\
\left.€ / \mathrm{m}^{3 \mathrm{~b}}\right)+ \text { (Cost of RGC }(29.52 \\
\left.\left.€ / \mathrm{m}^{3 \mathrm{c}}\right)\right)\end{array}$ & 48.47 \\
\hline
\end{tabular}

$\mathrm{Cm}=$ cost of waste management $=2.28 \mathrm{E}-02 € / \mathrm{m}^{3} ; \mathrm{CNA}=$ cost of natural aggregate; $\mathrm{CACp}=$ cost of aggregate concrete in plant; CMAp = cost of mixed aggregate in plant; $\mathrm{CW}_{\mathrm{NA}}=$ cost of water in the concrete with $\mathrm{NA} ; \mathrm{CW}_{\mathrm{ACp}}=$ cost of water in the concrete with aggregate concrete in plant.

aBEDEC (2015).

b Eq. (1). The amount of material used or substituted in the mixtures according to the composition of Table 1 was taken into account and data obtained from companies, organizations in Spain.

c Eq. (1)-(3). The amount of material used or substituted in the mixtures according to the composition of Table 1 was taken into account and data obtained from companies, organizations and recycling plants consulted.

tioned above, they refer to a linear interpolation of the measures $\mathrm{S}$ and $\mathrm{R}$.

\section{Conclusions}

In this study, the environmental and economic criteria of different alternatives for the production of structural and non-structural concrete were evaluated. MCDA was used to propose the best option or set of good alternative(s) for concrete production, considering both criteria. We compared the previously evaluated production of concrete from recycled gypsum cement and recycled aggregate with conventional concrete production.

The results of the study of environmental criteria indicate that the type of concrete that causes the greatest impact in all categories evaluated, except in the categories of carcinogenic and non-carcinogenic effects, is structural and non-structural concrete with $100 \%$ NA.
Moreover, the use of RGC in concrete production leads to a reduction in the impact in all of the categories evaluated. In the categories of respiratory organic and inorganic effects, eutrophication, land occupation, acidification, global warming, non-renewable energy and mineral extraction, recycled concrete leads to significant savings in the impacts.

The study of environmental criteria also indicates that the production of concrete with RA has a great weight in the categories of carcinogenic effects and mineral extraction categories. Therefore, both RCA and RMA have a greater impact on concrete in the category of carcinogenic effects, and higher savings in the category of mineral extraction. In the other categories, RGC plays a more important role in the final impact in relation to RA.

In the study of economic criteria, higher production costs were determined for the concrete with NA than for the concrete with RA. The lowest production costs were for SC20\%RCA-100\%RGC in the case of structural concrete, and NC100\%RCA-100\%RGC in the case of non-structural concrete. This confirms that the use of RCA and RGC in concrete leads to lower production costs.

The results of the multi-criteria method show that the best option was SC20\%RCA-100\%RGC for the production of structural concrete in all classifications of the evaluated criteria (with equal importance given to environmental and economic criteria or greater weight to one of the two criteria). The alternative chosen as the worst option was SC100\%NA for the production of structural concrete in all classifications of the criteria.

To implement the multi-criteria method in the production of non-structural concrete, the best options chosen for all classifications of the evaluated criteria were the two alternatives: NC100\%RCA-100\%RGC and NC75\%RMA-100\%RGC. The worst option for all classifications of the criteria in non-structural concrete was NC100\%NA.

Therefore, according to the results for environmental and economic criteria and the results of the multi-criteria method in which both criteria were taken into account, we can conclude that the use of recycled gypsum cement and recycled aggregate is beneficial to the production of conventional concrete.

The environmental and economic advantages found for the cleaner production of concrete may lead to the use of recycled gypsum cement and recycled aggregate as a replacement of the original raw material. It is hoped that this research can provide a breakthrough in cleaner concrete production, which leads to both a reduction of environmental impacts and economic savings.

All of the conclusions rely on the underlying assumptions of the study, the site-specific conditions for Spain (Barcelona), and the uncer-

Table 9

List of values $\mathrm{S}, \mathrm{R}$ and $\mathrm{Q}$ calculated in the production of non-structural concrete.

\begin{tabular}{|c|c|c|c|c|c|c|}
\hline Classification criteria & Alternatives & Qj & Alternatives & $\mathrm{Sj}$ & Alternatives & $\mathrm{Rj}$ \\
\hline \multirow[t]{5}{*}{ Equal importance } & A4 & 0.00 & A4 & 0.04 & A4 & 0.04 \\
\hline & A5 & 0.05 & A5 & 0.10 & A5 & 0.05 \\
\hline & A3 & 0.73 & A2 & 0.53 & $\mathrm{~A} 3$ & 0.29 \\
\hline & $\mathrm{A} 2$ & 0.77 & $\mathrm{~A} 3$ & 0.59 & A2 & 0.33 \\
\hline & $\mathrm{A} 1$ & 0.91 & $\mathrm{~A} 1$ & 0.94 & $\mathrm{~A} 1$ & 0.33 \\
\hline \multirow[t]{5}{*}{ Environmental advantage } & A4 & 0.00 & A4 & 0.05 & A4 & 0.05 \\
\hline & A5 & 0.04 & A5 & 0.09 & A5 & 0.07 \\
\hline & A3 & 0.78 & A2 & 0.64 & $\mathrm{~A} 3$ & 0.35 \\
\hline & A2 & 0.83 & A3 & 0.68 & A2 & 0.40 \\
\hline & $\mathrm{A} 1$ & 1.00 & $\mathrm{~A} 1$ & 0.94 & $\mathrm{~A} 1$ & 0.40 \\
\hline \multirow[t]{5}{*}{ Economical advantage } & A4 & 0.00 & A4 & 0.03 & A4 & 0.03 \\
\hline & A5 & 0.08 & A5 & 0.11 & A5 & 0.07 \\
\hline & $\mathrm{A} 2$ & 0.43 & A2 & 0.40 & $\mathrm{~A} 3$ & 0.22 \\
\hline & $\mathrm{A} 3$ & 0.44 & A3 & 0.48 & A2 & 0.25 \\
\hline & $\mathrm{A} 1$ & 1.00 & $\mathrm{~A} 1$ & 0.96 & $\mathrm{~A} 1$ & 0.50 \\
\hline
\end{tabular}

A1(NC100\%NA); A2(NC100\%RCA); A3(NC75\%RMA); A4(NC100\%RCA-100\%RGC); A5(NC75\%RMA-100\%RGC). 
tainty of the data. Further studies are recommended, to compare in greater depth the primary and secondary production of steel and its influence on the production of recycled aggregate concrete.

\section{Uncited references}

Cedex (2010), Concrete Permanent Commission (2008), Ferreira (2013), Poon and Chan (2006) and Anon. (2017).

\section{References}

Álvarez del Castillo, M.A., 2014. Management Analysis of Municipal Waste Generated in a Metropolitan Area Using a Multi-criteria Approach. [Análisis de la gestión de los residuos municipales generados en un entorno metropolitano utilizando un enfoque multicriterio]. Universitat Politècnica de Catalunya., Doctoral thesis.

Álvarez, L., 2010. Environmental Analysis of the Construction and Demolition Waste (CDW) Management. Focus on the Life Cycle Analysis (LCA) Perspective. Universitat Politècnica de Catalunya, Master thesis.

AFA, 2014. Association of Aggregate Manufacturers of Rioja, (Accessed October 18 2014) Available at: http://www.larioja.org/npRioja/default/defaultpage. jsp?idtab $=456440 \&$ IdDoc $=515711$.

ANEFHOP, 2015. Concrete Production Statistics Prepared, (Accessed August 3 2015). Available at: http://www.anefhop.com/component/content/article/ 126-estadisticas-prod/136-acceso-informes-produccion.

Anon., Alternative Aggregates for Sustainable Concrete Construction in the Amazon Region (PDF Download Available). Available from: https://www.researchgate.net/ publication/301790465_Alternative Aggregates for_Sustainable Concrete Construction in the Amazon Region (Accessed September 16, 2017).

ARC, 2015. Agència de Residus de Catalunya, (Accessed March 3 2015). Available at: http: //residus.gencat.cat/es/consultes i tramits - nou/consultes/.

Ahmed, A., Ugai, K., Kamei, T., 2011. Laboratory and field evaluations of recycled gypsum as a stabilizer agent in embankment construction. Soils Found. 51 (6), 975-990.

Akadiri, O., Olomolaiye, P.O., Chinyio, E.A., 2013. Multi-criteria evaluation model for the selection of sustainable materials for building projects. Autom. Constr. 30, 113-125.

Alaejos, P., 2008. Types and Properties of Recycled Aggregates. CEDEX report for the Ministry of Environment., Spain.

Anastasiou, E., Filikas Georgiadis, K., Stefanidou, M., 2014. Utilization of fine recycled aggregates in concrete with fly ash and steel slag. Constr. Build. Mater. 50, 154-161.

Bedec (ITEC) Batabase, Institut de tecnologia de la Construcció de Catalunya. Catalunya. Spain, 2015, Available at: http://itec.es/nouBedec.e/bedec.aspx.

Bahraminasab, M., Jahan, A., 2011. Material selection for femoral component of total knee replacement using comprehensive VIKOR. Mater. Des. 32, 4471-4477.

Behera, M., Bhattacharyya, S.K., Minocha, A.K., Deoliya, R., Maiti, S., 2014. Recycled aggregate from C\&D waste \& its use in concrete -a breakthrough towards sustainability in construction sector: a review. Constr. Build. Mater. 68, 501-516.

Bel-

ton

ton

Stew-

art,

2002 V. Belton, T.J. Stewart, Multiple Criteria Decision Analysis: an Integrated Approach, Kluwer Academic Publisher, 2002.

Benveniste, G., Gazulla, C., Fullana, P., Celades, I., Ros, T., Zaera, V., Godes, B., 2011. Life cycle assessment and product category rules for the construction sector. The floor and wall tiles sector case study. Informes de la construcción 63 (552), 71.

Birgisdóttir, H., Pihl, K., Bhander, G., Hauschild, M., Christensen, T., 2006. Environmental assessment of roads constructed with and without bottom ash from municipal solid waste incineration. Transp. Res. D: Transp. Environ. 5, 358-368.

Blengini, Gian Andrea, Di Carlo, Tiziana, 2010. The changing role of life cycle phases, subsystems and materials in the LCA of low energy buildings. Energy Build. 42 (6), 869-880.

CEN/TC350, 2012. Sustainability of Construction Works. European Committee for Standardisation, Available at: http://portailgroupe.afnor.fr/public_espacenormalisation/ CENTC350/index.html.

Castell, Albert, Menoufi, Karim, de Gracia, Alvaro, Rincón, Lidia, Boer, Dieter, Cabeza, Luisa F., 2013. Life Cycle Assessment of alveolar brick construction system incorporating phase change materials (PCMs). Appl. Energ. 101, 600-608.

Cedex, 2010. Construction and Demolition Waste. 2010. Technical Specifications. Ministry of Public Works. Ministry of the Environment. Centre for Public Works Studies and Experimentation.

Chandara, C., Azizli, K.A.M., Ahmd, Z.A., Sakai, E., 2009. Use of waste gypsum to replace natural gypsum as set retarders in portland cement. Waste Manage. 29 (5), $1675-1679$.

Chen, Xi, Weisheng, L.U., 2017. Identifying factors influencing demolition waste generation in Hong Kong. J. Clean. Prod. 141, 799-811.

Ciment Catalá, 2015. Asociación de Fabricantes de cemento de Cataluña. Plantas de fabricación de cemento en Cataluña, (Accessed July 11 2015). Available at: http://www. cimentcatala.org/ePub/easnet.dll/execreq/page?eas:dat_im = 001791\&eas:template im $=001341$.
Cinelli, M., Coles, S.R., Kirwan, K., 2014. Analysis of the potentials of multi criteria decision analysis methods to conduct sustainability assessment. Ecol. Indic. 46, 138-148.

Civic, Adnan, Vucijak, Branko, 2014. Multi-criteria optimization of insulation options for warmth of buildings to increase energy efficiency. Procedia Eng. 69, 911-920.

Coelho, André, De Brito, Jorge, 2013. Economic viability analysis of a construction and demolition waste recycling plant in Portugal -part I: location, materials, technology and economic analysis. J. Clean. Prod. 39, 338-352.

Coelho, André, De Brito, Jorge, 2013. Economic viability analysis of a construction and demolition waste recycling plant in Portugal -part II: economic sensitivity analysis. J. Clean. Prod. 39, 329-337.

Concrete Permanent Commission, 2008. (CPH) Instrucción Del Hormigón Estructural EHE-08 (Spanish Structural Concrete Code). Spanish Minister of Public Works, Madrid, Spain.

Corinaldesi, Valeria, Moriconi, Giacomo, 2009. Influence of mineral additions on the performance of $100 \%$ recycled aggregate concrete. Constr. Build. Mater. 23 (8), 2869-2876.

de Bravo, Miguel, Brito, Jorge, Pontes, Jorge, Evangelista, Luís, 2015. Durability performance of concrete with recycled aggregates from construction and demolition waste plants. Constr. Build. Mater. 77, 357-369.

DIN 4226-100, 2002. Aggregates for Concrete and Mortar - Part 100: Recycled Aggregates.

Dong, Y.H., N.G.S.T, Kwana, A.H.K., Wub, S.K., 2015. Substituting local data for overseas life cycle inventories -a case study of concrete products in Hong Kong. J. Clean. Prod. $87,414-422$.

Eurostat environment and energy, 2010. Generation and Treatment of Waste, http://ec europa.eu/eurostat/ Available in (Accessed May 18 2014).

Evangelista, L., De Brito, J., 2010. Durability performance of concrete made with fine recycled concrete aggregates. Cem. Concr. Compos. 32 (1), 9-14.

Faella, C., Lima, C., Martinelli, E., Pepe, M., Realfonzo, R., 2016. Mechanical and durability performance of sustainable structural concretes: an experimental study. Cem. Concr. Compos. 71, 85-96.

Ferreira, Tiago, 2013. Concrete Incorporating Ceramic Recycled Fine Aggregate. Technical Lisbon, Portugal, Thesis of master.

GRI, 2015. Gypsum Recycling International, (Accessed July 15 2015). Available at: http: //www.gypsumrecycling.biz/15841-1_GypsumRecycling.

García, Leyton, Luís, Alberto, 2004. Application of Multi-criteria Analysis in Assessing Environmental Impacts. [Aplicación del análisis multicriterio en la evaluación de impactos ambientales]. Universitat Politècnica de Catalunya. Departament de Projectes d'Enginyeria, Barcelona, Spain.

García, C., $\mathrm{M}^{\circ}$ Del Socorro, 2009. Methods for Comparison of Alternatives by a System Decision Support (sds) and Soft Computing. [Métodos para la comparación de alternativas mediante un Sistema de Ayuda a la Decisión (S.A.D.) y « Soft Computing ». Department of Electronics, Computer Technology and Projects, Polytechnic University of Cartagena, Murcia, Spain, Doctoral thesis.

Geraldes, V.L., 2013. Study on Non-Structural Recycled Concretes with Mixed Recycled Aggregate: Mechanical Properties and Expansion Due to Sulphates. Universidad Politécnica de Madrid, Madrid, Spain, in Spanish.

Ghanimeh, S., Jawad, D., Semaan, P., 2016. Quantification of construction and demolition waste: a measure toward effective modeling. In: 3rd International Conference on Advances in Computational Tools for Engineering Applications (ACTEA). Beirut, Lebanon. September 83-86.

Godinho-Castro, A.P., Testolin, R.C., Janke, L., Corréa, A.X.R., Radetski, C.M., 2012. Incorporation of gypsum waste in ceramic block production: proposal for a minimal battery of tests to evaluate technical and environmental viability of this recycling process. Waste Manage. 32 (1), 153-157.

González-Corominas, et al., 2014. Properties of high performance concrete made with recycled fine ceramic and coarse mixed aggregates. Constr. Build. Mater. 68, 618-626.

Gremi d'Àrids de Catalunya, 2015. Extracció I Tractament d'àrids Al Territori Català, (Accessed: 11 July 2015). Available at: http://www.gremiarids.com/ca/que-es-el-gremi. html.

Gypsum Recycling International, http://www.gypsumrecycling.biz/, (Last accessed June 2, 2014).

Hermann, B.G., Kroeze, C., Jawjit, W., 2007. Assessing environmental performance by combining life cycle assessment, multi-criteria analysis and environmental performance indicators. J. Clean. Prod. 15 (18), 1787-1796.

Hiete, Michael, Stengel, Julian, Ludwig, Jens, Schultmann, Frank, 2011. Matching construction and demolition waste supply to recycling demand: a regional management chain model. Build. Res. Inf. 39, 333-351.

Hossain, U. Md., Poon, C.S., Lo, I.M.C., Cheng, J.C.P., 2016. Comparative environmental evaluation of aggregate production from recycled waste materials and virgin sources by LCA. Resour. Conserv. Recycl. 109, 67-77.

Imbabi, M.S., Carrigan, C., Mckenna, S., 2012. Trends and developments in green cement and concrete technology. Int. J. Sustainable Built Environ. 1 (2), 194-216.

Jato-Espino, D., Castillo-Lopez, E., Rodriguez-Hernandez, J., Canteras-Jordana, J.C., 2014 A review of application of multi-criteria decision making methods in construction. Autom. Constr. 45, 151-162.

Jolliet, Oliver, et al., 2014. Global guidance on environmental life cycle impact assessmen indicators: findings of the scoping phase. Int. J. Life Cycle Assess. 19 (4), 962-967.

Kim, S., Choi, M., Mha, H., Joung, J., 2013. Environmental impact assessment and eco-friendly decision-making in civil structures. J. Environ. Manage. 126, 105-112. 
Kleijer, A.L., Lasvaux, S., Citherlet, S., Viviani, M., 2017. Product-specific life cycle assessment of ready mix concrete: comparison between a recycled and an ordinary concrete. Resour. Conserv. Recycl. 122, 210-218.

Kofoworola, O., Gheewala, S., 2009. Life cycle energy assessment of a typical office building in Thailand. Energy Build. 10, 1076-1083.

Kylili, Angeliki, Fokaides, Paris A., 2016. Life cycle assessment (LCA) of phase change materials (PCMs) for building applications: a review. J. Build. Eng. 6, 133-143.

Li, Xiaodong, Zhu, Yimin, Zhang, Zhihui, 2010. An LCA-based environmental impact assessment model for construction processes. Build. Environ. 45 (3), 766-775.

López, Fernando, 2008. Influence of Variation of Dosage Parameters and Manufacture of Structural Recycled Concrete over Their Physical and Mechanical Properties. University of Oviedo. Construction department and manufacturing engineering, Spain, Doctoral thesis. pp.328.

Lasvaux, S., Schiopu, N., Habert, G., Chevalier, J., Peuportier, B., 2014. Influence of simplification of life cycle inventories on the accuracy of impact assessment: application to construction products. J. Clean. Prod. 79, 142-151.

Lima, C., Caggiano, A., Faella, C., Martinelli, E., Pepe, M., Realfonzo, R., 2013. Physical properties and mechanical Behaviour of concrete made with recycled aggregates and fly ash. Constr. Build. Mater. 47, 547-559.

Lu, W., Yuan, W., 2011. A framework for understanding waste management studies in construction. Waste Manage. 31, 1252-1260.

Marinković, S., Radonjanin, V., Malešev, M., Ignjatović, I., 2010. Comparative environmental assessment of natural and recycled aggregate concrete. Waste Manage. 30 (11), 2255-2264.

Matias, D., de Brito, J., Rosa, A., Pedro, D., 2013. Mechanical properties of concrete produced with recycled coarse aggregates -influence of the use of superplasticizers. Constr. Build. Mater. 44, 101-109.

Medina, C., Frías, M., Sánchez de Rojas, M.I., 2012. Microstructure and properties of recycled concretes using ceramic sanitary ware industry waste as coarse aggregate. Constr. Build. Mater. 31, 112-118.

Mercante, Irma, Edo, M., Forés, V., Arena, A., 2010. Environmental profile of the construction and demolition waste management. Life cycle inventories development. In: 3rd Iberoamerican Symposium in Waste Engineering. Brazil, September 8-10.

Ministry of Industry Energy and Tourism, 2015. Statistics Miner Spain, (Accessed September 4 2015). Available at: http://www.minetur.gob.es/energia/mineria/Estadistica/ Datos anuales/anual 2013.pdf.

Mir, M.A., Ghazvinei, P.T., Sulaiman, N.M.N., Basri, N.E.A., Saheri, S., Mahmood, N.Z., et al., 2016. Application of TOPSIS and VIKOR improved versions in a multi criteria decision analysis to develop an optimized municipal solid waste management model. J. Environ. Manage. 166, 109-115.

Morales Martinez, L., 2010. Reuse of Building Material Waste for the Development of Cementitious Materials with Special Characteristics (Reutilizaci_on De Residuos De Edificaci_on Para El Desarrollo De Materiales Cementantes Con Características Especiales). Polytechnic University of Catalonia, Master thesis.

Opricovic, Serafim, Tzeng, Gwo-Hshiung, 2007. Extended \{VIKOR $\}$ method in comparison with outranking methods. Eur. J. Oper. Res. 178 (2), 514-529. Opri-

covic,

1998 S. Opricovic, Multicriteria Optimization of Civil Engineering Systems, 1998, Belgrade.

Ortiz, Oscar, Pasqualino, J.C., Castells, F., 2010. Environmental performance of construction waste: comparing three scenarios from a case study in Catalonia, Spain. Waste Manage. 30 (4), 646-654.

Ossa, A., García, J.L., Botero, E., 2016. Use of recycled construction and demolition waste (CDW) aggregates: a sustainable alternative for the pavement construction industry. J. Clean. Prod. 135, 379-386.

Pepe, M., Toledo Filho, R.D., Koenders, E.A.B., Martinelli, E., 2014. Alternative processing procedures for recycled aggregates in structural concrete. Constr. Build. Mater. 69, 124-132.

Pohekar, S., Ramachandran, M., 2004. Application of multi-criteria decision making to sustainable energy planning - a review. Renew. Sustain. Energy Rev. 8 (4), 365-381.

Pons, O., Aguado, A., 2012. Integrated value model for sustainable assessment applied to technologies used to build schools in Catalonia, Spain. Build. Environ. 53, 49-58.

Poon, Chi Sun, Chan, Dixon, 2006. Paving blocks made with recycled concrete aggregate and crushed clay brick. Constr. Build. Mater. 20 (8), 569-577.

Poon, C., Shui, Z.H., Lam, L., Fok, H., Kou, S.C., 2004. Influence of moisture states of natural and recycled aggregates on the slump and compressive strength of concrete. Cem. Concr. Res. 34 (1), 31-36.
Quijano, Ricardo, 2012. Design and Implementation of an Integrated Modeling for Sustainable Energy Planning-modergis- Platform Case Study Colombia. [Diseño E Implementación De Una Plataforma Integrada De Modelación Para La Planificación Energética Sostenible-modergis-Estudio. School of Mines, National University of Colombia, Colombia.

Reza, B., Sadiq, R., Hewage, K., 2011. Sustainability assessment of flooring systems in the city of Tehran: an AHP-based life cycle analysis. Constr. Build. Mater. 25, 2053-2066.

Rincón, Lídia, Coma, Julià, Pérez, Gabriel, Castell, Albert, Boer, Dieter, Cabeza, Luisa F, 2014. Environmental performance of recycled rubber as drainage layer in extensive green roofs. A comparative Life Cycle Assessment. Build. Environ. 74, 22-30.

Sánchez de Juan, Marta, Alaejos, Pilar, Geraldes, Victor, Vegas, Iñigo, Girbes, Isabel, Marti, Pilar, Agrela, Francisco, Ayuso, Jesús, 2011. Mixed Use of Recycled Aggregates from Construction and Demolition Waste [Uso de áridos reciclados mixtos procedentes de Residuos de Construcción y Demolición]. Ihobe. Department for the Environment, Land Use planning, Agriculture and Fisheries. Basque Government, Spain.

Sánchez de Juan, Marta, 2004. Study on the Use of Recycled Aggregate for the Manufacture of Structural Concrete. [Estudio Sobre La Utilización De árido Reciclado Para La Fabricación De Hormigón Estructural]. Doctoral Thesis. Polytechnic University of Madrid, Madrid, Spain.

Sánchez de Juan, 2011. Recycled Aggregates for Non-Structural Concrete Applications. Central Laboratory of Structures and Materials (CEDEX). I Building Week. Official Association of Architects, Technical Architects and Building Engineers of Madrid, Madrid, March 2011.

SIMAPRO, 2008. Manual de base de datos. Métodos. Pré consultants. 2008. Países Bajos.

Smith, R.A., Kersey, J.R., Griffiths, P.J., 2002. The Construction Industry Mass Balance: Resource Use, Wastes and Emissions, Virdis, Report VR4.

Srubar, Will, 2015. Stochastic service-life modeling of chloride-induced corrosion in recycled-aggregate concrete. Cem. Concr. Compos. 55, 103-111.

Suganthi, L., Iniyan, S., Samuel, Anand A., 2015. Applications of fuzzy logic in renewable energy systems -A review. Renew. Sustain. Energy Rev. 48, 85-607.

Tam, Vivian W.Y., 2008. Economic comparison of concrete recycling: a case study ap proach. Resour. Conserv. Recycl. 52 (5), 821-828.

Tatari, O., Kucukvar, M., 2011. Evaluating eco-efficiency of construction materials: a frontier approach. Comput. Civil Eng. 736-743.

Tošić, Nikola, Marinković, Snežana, Dašić, Tina, Stanić, Miloš, 2015. Multicriteria optimization of natural and recycled aggregate concrete for structural use. J. Clean. Prod. 87, 766-776.

Turk, Janez, Cotič, Zvonko, Mladenovič, Ana, Šajna, Aljoša, 2015. Environmental evaluation of green concretes versus conventional concrete by means of LCA. Waste Manage. 45, 194-205.

U.S. Geological Survey, 2017. Mineral commodity summaries 2017. U.S. Geol. Surv. 202, https://doi.org/10.3133/70180197, p-44.

Vahabzadeh, Ali Haji, Asiaei, Arash, Zailani, Suhaiza, 2015. Green decision-making model in reverse logistics using FUZZY-VIKOR method. Resour. Conserv. Recycl. 103, 125-138.

Vučijak, B., Kurtagić, S.M., Silajdžić, I., 2016. Multicriteria decision making in selecting best solid waste management scenario: a municipal case study from Bosnia and Herzegovina. J. Clean. Prod. 130, 166-174.

WRAP, 2008. Trials for the Use of Recycled Gypsum in Cement Manufacture. Report Demonstrating the Potential to Use Recycled Gypsum in the Manufacture of Cement Partially or Fully in Place of Natural Gypsum. United Kingdom, ISBN 1-84405-404-7.

Zabalza Bribián, Ignasio, Valero Capilla, Antonio, Aranda Usón, Alfonso, 2011. Life cycle assessment of building materials: comparative analysis of energy and environmental impacts and evaluation of the eco-efficiency improvement potential. Build. Environ. 46 (5), 1133-1140.

Zabalza Bribián, Ignasio, 2012. EnerBuiLCA Project: development of a database and a life cycle assessment tools for buildings adapted to the region southwest Europe. CONAMA 2012. Technical Communication. National Environmental Congress

Zazurca Ruiz-Cerdà, S., 2012. Environmental Study of a Detached House in Barcelona. Final Degree Project. Universitat Politècnica de Catalunya, Spain. 